\title{
Przetwarzanie i ochrona danych dotyczących zdrowia przez organizatora systemu opieki zdrowotnej
}

\section{Wprowadzenie}

Ochrona osób fizycznych w związku z przetwarzaniem danych osobowych jest jednym z praw podstawowych. Artykuł 8 ust. 1 Karty praw podstawowych Unii Europejskiej ${ }^{1}$ (KPP) oraz art. 16 ust. 1 Traktatu o funkcjonowaniu Unii Europejskiej (TFUE) ${ }^{2}$ stanowią, że każda osoba ma prawo do ochrony danych osobowych jej dotyczących. Nie jest ono jednak prawem bezwzględnym; należy je postrzegać w kontekście jego funkcji społecznej i wyważyć względem innych praw podstawowych w myśl zasady proporcjonalności ${ }^{3}$. Z tego też względu Rozporządzenie Parlamentu Europejskiego i Rady (UE) z dnia 27 kwietnia 2016 r. w sprawie ochrony osób fizycznych $\mathrm{w}$ związku z przetwarzaniem danych osobowych i w sprawie swobodnego przepływu takich danych oraz uchylenia dyrektywy 95/46/WE (ogólne rozporządzenie o ochronie danych - RODO) zawiera ponad 70 odesłań do decyzji ustawodawców krajowych. W konsekwencji w piśmiennictwie trafnie określone zostało "hybrydą rozporządzenia i dyrektywy" ${ }^{\text {. }}$.

* Daniel Eryk Lach, prof. UAM dr hab., Uniwersytet im. Adama Mickiewicza w Poznaniu, e-mail: lach@amu.edu.pl, http://orcid.org/0000-0001-6223-5356.

${ }^{1}$ Dz.Urz. UE C 202 z 7 VI 2016 r.

${ }^{2}$ Dz.Urz. UE C 202 z 7 VI 2016 r.

${ }^{3}$ Por. pkt 1 i 4 preambuły RODO.

${ }^{4}$ Dz.Urz. UE L 119 z 4 V 2016 r.

${ }^{5}$ Por. B. Buchner, S. Schwichtenberg, Gesundheitsdatenschutz unter der Datenschutz-Grundverordnung, "Gesundheit und Praxis" 2016, Nr. 6, s. 219. 
Wspomniane odesłania odnoszą się między innymi do "danych dotyczących zdrowia", które nie były definiowane na gruncie dyrektywy 95/46/WE Parlamentu Europejskiego i Rady z dnia 24 października 1995 r. w sprawie ochrony osób fizycznych w zakresie przetwarzania danych osobowych i swobodnego przepływu tych danych ${ }^{6}$. Pojęcie to RODO definiuje jako dane osobowe o zdrowiu fizycznym lub psychicznym osoby fizycznej - w tym o korzystaniu z usług opieki zdrowotnej ujawniające informacje o stanie jej zdrowia (art. 4 pkt 15 RODO) ${ }^{7}$, które podlegają zbieraniu i przetwarzaniu w systemie opieki zdrowotnej i na jego potrzeby. Warto przy tym zauważyć, że do danych osobowych dotyczących zdrowia należy zaliczyć wszystkie dane o stanie zdrowia osoby, której dane dotycza, ujawniające informacje o przeszłym, obecnym lub przyszłym stanie fizycznego lub psychicznego zdrowia osoby, której dane dotyczą. Do danych takich należą informacje o danej osobie fizycznej zbierane podczas jej rejestracji do usług opieki zdrowotnej lub podczas świadczenia jej usług opieki zdrowotnej, jak to określa dyrektywa Parlamentu Europejskiego i Rady 2011/24/UE: numer, symbol lub oznaczenie przypisane danej osobie fizycznej w celu jednoznacznego zidentyfikowania tej osoby fizycznej do celów zdrowotnych; informacje pochodzące $z$ badań laboratoryjnych lub lekarskich części ciała lub płynów ustrojowych, w tym danych genetycznych i próbek biologicznych; oraz wszelkie informacje, np. o chorobie, niepełnosprawności, ryzyku choroby, historii medycznej, leczeniu klinicznym lub stanie fizjologicznym lub biomedycznym osoby, której dane dotycza, niezależnie od ich źródła, którym może być np. lekarz lub inny pracownik służby zdrowia, szpital, urządzenie medyczne lub badanie diagnostyczne in vitro ${ }^{8}$. Jest to zatem pojęcie niezwykle szerokie, które należy rozumieć w najszerszym możliwym sensie9.

W kontekście swobody ustawodawcy krajowego dotyczącej odmiennego od przewidzianego w RODO uregulowania przetwarzania danych dotyczących zdrowia należy, po pierwsze, przywołać pkt 10 preambuły RODO, który w odniesieniu do przetwarzania danych osobowych

${ }^{6}$ Por. M. Kuba, Komentarz do art. 9, pkt 9, w: RODO. Ogólne rozporzadzenie o ochronie danych. Komentarz, pod red. E. Bielak-Jomaa, D. Lubasza, Warszawa 2018.

${ }^{7}$ Krytycznie na temat tej definicji A. Dmochowska, Przetwarzanie danych szczególnych kategorii, w: A. Dmochowska, M. Zadrożny, Unijna reforma ochrony danych osobowych. Analiza zmian, Warszawa 2016, s. 30.

${ }^{8}$ Por. pkt 35 preambuły RODO.

${ }^{9}$ Por. wyrok TSUE z 6 XI 2003 r. w sprawie C-101/01, Lindquist, Nb. 50. 
w celu wypełnienia obowiązku prawnego, w celu wykonania zadania realizowanego $\mathrm{w}$ interesie publicznym lub $\mathrm{w}$ ramach sprawowania władzy publicznej powierzonej administratorowi, wskazuje, że państwa członkowskie powinny móc zachować lub wprowadzić krajowe przepisy doprecyzowujące stosowanie przepisów niniejszego rozporządzenia. W konsekwencji art. 6 ust. 1 lit. e RODO stanowi, że przetwarzanie danych jest zgodne $z$ prawem m.in. wtedy, gdy jest ono niezbędne do wykonania zadania realizowanego $\mathrm{w}$ interesie publicznym lub $\mathrm{w}$ ramach sprawowania władzy publicznej powierzonej administratorowi, natomiast na mocy art. 6 ust. 2 RODO państwa członkowskie mogą zachować lub wprowadzić bardziej szczegółowe przepisy, aby dostosować stosowanie przepisów RODO w odniesieniu do przetwarzania służącego wypełnieniu warunków określonych w ust. 1 lit. c i e; dlatego mogą dokładniej określić szczegółowe wymogi przetwarzania i inne środki w celu zapewnienia zgodności przetwarzania $z$ prawem i jego rzetelności, także w innych szczególnych sytuacjach związanych z przetwarzaniem, przewidzianych $\mathrm{w}$ rozdziale IX RODO.

Odnośnie do kwestii, czy NFZ, będąc organizatorem systemu opieki zdrowotnej, wykonuje tym samym - jako "administrator" - zadania realizowane $\mathrm{w}$ interesie publicznym lub $\mathrm{w}$ ramach sprawowania władzy publicznej, należy przywołać rozważania dotyczące zdefiniowania techniki powierniczej jako nowej metody urzeczywistniania idei zabezpieczenia społecznego ${ }^{10}$ opartej na ideologii państwa mocodawczego (ang. the enabling state) ${ }^{11}$, względnie państwa gwarantującego (niem. Gewährleistungsstaat $)^{12}$. Są one określane w literaturze jako „trzecia droga między klasycznym państwem interwencjonizmu państwowego a państwem dobrobytu"13. W tej koncepcji państwo - odmiennie niż

${ }^{10}$ Por. D.E. Lach, Powiernicza technika realizacji zabezpieczenia społecznego (na przykładzie ubezpieczenia zdrowotnego), „Państwo i Prawo” 2009, z. 3; idem, Powierzanie realizacji zadań publicznych z zakresu zabezpieczenia społecznego podmiotom niepublicznym, „Państwo i Prawo" 2015, z. 2.

${ }^{11}$ Por. J. Jończyk, Trudna modernizacja opieki zdrowotnej w Niemczech i w Zjednoczonym Królestwie (UK), „Praca i Zabezpieczenie Społeczne” 2006, nr 6, s. 6.

${ }_{12}$ Por. C. Franzius, Der "Gewährleistungsstaat" - ein neues Leitbild für den sich wandelnden Staat?, "Der Staat" 2003, Bd. 42, s. 493-494; idem, Die Europäische Dimension des Gewährleistungsstaates, "Der Staat” 2006, Bd. 45, s. 547 i n.; idem, Gewährleistung im Recht. Grundlagen eines europäischen Regelungsmodells öffentlicher Dienstleistungen, Tübingen 2009, s. 24 i n., 39.

${ }^{13} \mathrm{H}$. Szurgacz, Zagadnienie przekazywania przez państwo zadań w zakresie zabezpieczenia społecznego podmiotom niepublicznym, w: Konstytucyjne problemy prawa pracy i zabezpieczenia społecznego. Referaty na XV Zjazd Katedri Zakładów Prawa Pracy i Ubezpieczeń Społecznych, Wrocław 1-2 czerwca 2005 r., pod red. H. Szurgacza, Wrocław 2005, s. 132. 
państwo opiekuńcze, urzeczywistniające technikę zaopatrzeniową (za pośrednictwem tzw. administracji świadczącej) - samodzielnie nie realizuje rozmaitych świadczeń z zakresu zabezpieczenia społecznego ${ }^{14}$, ale organizuje ramy prawne i wytycza zadania profesjonalnym podmiotom zastępującym je $\mathrm{w}$ tej roli ${ }^{15}$, co powiązane jest $\mathrm{z}$ koncepcjami prywatyzacji zadań publicznych ${ }^{16}$ oraz kooperacyjnej formy działania władz publicznych ${ }^{17}$. W odniesieniu do systemu opieki zdrowotnej NFZ - organizator systemu - występuje w roli powiernika, którego zadaniem jest jedynie zarządzanie środkami finansowymi i zawieranie we własnym imieniu umów o świadczenia opieki zdrowotnej z niezależnymi świadczeniodawcami oraz ich rozliczanie. Warto podkreślić, że w odróżnieniu od techniki ubezpieczeniowej i zaopatrzeniowej powiernik (NFZ) nie jest zobowiązany do spełniania świadczeń ani samodzielnie, ani za pomocą świadczeniodawców. Jego zadaniem jest tylko administrowanie otrzymywanymi środkami, z zastrzeżeniem, że czyni to na rzecz i w interesie beneficjentów systemu, co będzie mieć swoje konsekwencje przy ocenie jego działań zarządczych i organizatorskich, przede wszystkim zawieranych ze świadczeniodawcami umów o świadczenie opieki zdrowotnej. Można zatem uznać, że jest on takim właśnie administratorem wykonującym zadania realizowane $\mathrm{w}$ interesie publicznym - podmiotem powołanym do pełnienia roli realizatora systemu opieki zdrowotnej jako subsystemu zabezpieczenia społecznego. Teza ta jest tym bardziej uzasadniona, że ostatnimi czasy można zaobserwować trend (re)publicyzacji zadań publicznych, przede wszystkim w odniesieniu do usług komunalnych ${ }^{18}$. Proces ten dotyczy

${ }^{14} \mathrm{~S}$. Biernat pisał w tym kontekście o „rezygnacji z omnipotencji i paternalizmu państwa" (S. Biernat, Prywatyzacja zadań publicznych. Problematyka prawna, WarszawaKraków 1994, s. 7, 9).

${ }^{15}$ J. Jończyk wskazywał w tym kontekście na koncepcję odróżnienia klasycznej cywilnoprawnej twardej umowy (ang. hard contracting) od nowego typu umowy miękkiej (ang. soft contracting), której celem jest nawiązanie trwałej kooperacji między stronami ze względu na wspólny cel, co dotyczy zwłaszcza sytuacji, gdy stroną dominującą jest podmiot publiczny dysponujący środkami publicznymi (J. Jończyk, Glosa do wyroku SN z dnia 10 grudnia 2004 r., III CK 134/04, OSP 2005, z. 6, s. 333).

${ }^{16}$ Por. S. Biernat, op. cit.

${ }_{17}$ Por. E. Treutner, Kooperativer Rechtsstaat. Das Beispiel Sozialverwaltung, Baden-Baden 1998.

${ }^{18} \mathrm{~W}$ literaturze niemieckiej przywoływany jest kazus Poczdamu, który już w roku 2000 zdecydował się na rezygnację z partnerstwa publiczno-prywatnego w odniesieniu do usług wodociągowo-kanalizacyjnych i ich rekomunalizację. Por. H. Bauer, Privatisierung oder Publizisierung?, w: Publizisierung öffentlicher Aufgaben, Hrsg. von H. Bauer, 
jednak (a przynajmniej może dotyczyć) także instytucji i zakładów socjalnych: przedszkoli, ośrodków dla seniorów i młodzieży, budowy i obsługi mieszkań komunalnych, prowadzenia szpitali itp. ${ }^{19} \mathrm{~W}$ tym kontekście przywołać można np. powtarzające się zapowiedzi „likwidacji NFZ", a w konsekwencji publicyzacji systemu opieki zdrowotnej lub co najmniej wykonawcy zadań publicznych z zakresu opieki zdrowotnej ${ }^{20}$, oraz zmiany dotyczące systemu ratownictwa medycznego sprowadzające się do ograniczenia kręgu potencjalnych świadczeniodawców do podmiotów publicznych lub z dominującym publicznym udziałowcem ${ }^{21}$.

Dostrzec jednak trzeba, że podstawy prawne przetwarzania danych osobowych wskazane w art. 6 RODO dotyczą tzw. danych zwykłych, a więc innych niż tzw. dane wrażliwe, wśród nich dane dotyczące zdrowia ${ }^{22}$. W kontekście reguł RODO dotyczących przetwarzania danych dotyczących zdrowia przywołać należy zatem art. 9 ust. 2, który zezwala na takie przetwarzanie tych danych, które jest niezbędne do wypełniania obowiązków i wykonywania szczególnych praw przez administratora lub osobę, której dane dotycza, w dziedzinie prawa pracy, zabezpieczenia społecznego i ochrony socjalnej (lit. b), oraz które jest niezbędne do celów medycznych zapewnienia opieki zdrowotnej lub zabezpieczenia społecznego, leczenia lub zarządzania systemami i usługami opieki zdrowotnej lub zabezpieczenia społecznego (lit. h). Należy przy tym zauważyć, że dla stwierdzenia dopuszczalności przetwarzania szczególnych kategorii danych w oparciu o przesłanki wskazane w art. 9 ust. 2 lit. h RODO nie wystarczy wykazanie realizacji jednego z wymienionych w tym przepisie celów, potrzeba jeszcze istnienia szczególnego przepisu prawa (unijnego bądź krajowego) albo umowy, na podstawie

M. Szewczyk, B. Popowska, M. Meier, A. Fuks, Potsdam 2018, s. 18-20, idem, Von der Privatisierung zur Rekommunalisierung, w: Rekommunalisierung öffentlicher Daseinsvorsorge, Hrsg. von H. Bauer, Ch. Büchner, L. Hajasch, Potsdam 2012, s. 13-15.

${ }_{19}$ Por. H. Bauer, Von der Privatisierung..., s. 22-24; R. Schäfer, Rekommunalisierung Fallstricke in der Praxis, w: Rekommunalisierung..., s. 73.

${ }^{20}$ Por. D.E. Lach, Tendencje rozwojowe "ubezpieczenia zdrowotnego" - kilka uwag na marginesie zapowiadanej publicyzacji systemu opieki zdrowotnej, w: Tendencje rozwojowe indywidualnego i zbiorowego prawa pracy. Księga jubileuszowa Profesora Grzegorza Goździewicza, Toruń 2017, s. 687-695.

${ }^{21}$ Por. D.E. Lach, Pojęcie i systematyka prawa ubezpieczeń społecznych, w: System prawa ubezpieczeń społecznych, t. 1, pod red. A. Wypych-Żywickiej, Warszawa 2020, s. 33 i n., 35.

${ }^{22}$ Por. A. Mednis, Ochrona danych osobowych w systemie ochrony zdrowia. Zasady prowadzenia, udostęniania i archiwizowania dokumentacji medycznej, w: Organizacja systemu ochrony zdrowia. System Prawa Medycznego, t. 3, pod red. D. Bach-Goleckiej, R. Stankiewicza, Warszawa 2020, s. 944. 
których przetwarzanie tego rodzaju danych jest dopuszczalne ${ }^{23}$. Jak się wydaje, w tym kontekście odczytywać trzeba także statuowany w art. 9 ust. 3 RODO wymóg, aby dane dotyczące zdrowia były przetwarzane przez - lub na odpowiedzialność - pracownika podlegającego obowiązkowi zachowania tajemnicy zawodowej na mocy prawa Unii lub prawa państwa członkowskiego, lub przepisów ustanowionych przez właściwe organy krajowe lub przez inną osobę również podlegającą obowiązkowi zachowania tajemnicy zawodowej na mocy prawa Unii lub prawa państwa członkowskiego, lub przepisów ustanowionych przez właściwe organy krajowe. Ponadto RODO stanowi, że państwa członkowskie mogą zachować lub wprowadzić dalsze warunki, w tym ograniczenia w odniesieniu do przetwarzania danych genetycznych, danych biometrycznych lub danych dotyczących zdrowia (art. 9 ust. 4 RODO).

W rezultacie można uznać, że to ustawodawstwo krajowe odgrywa zasadniczą rolę w określaniu, wprowadzaniu lub utrzymywaniu warunków, w tym ograniczeń, w odniesieniu do gromadzenia i przetwarzania danych dotyczących zdrowia. Niemniej jednak, niezależnie od przepisów szczegółowych lub odesłań do ustawodawstwa krajowego, RODO w art. 5 określa zasady ogólne przetwarzania danych osobowych, w tym danych dotyczących zdrowia. Przepis ten w ust. 1 stanowi, że dane osobowe muszą być: 1) przetwarzane zgodnie z prawem, rzetelnie i w sposób przejrzysty dla osoby, której dane dotyczą ( „zgodność z prawem, rzetelność i przejrzystość"); 2) zbierane w konkretnych, wyraźnych i prawnie uzasadnionych celach i nieprzetwarzane dalej w sposób niezgodny z tymi celami ("ograniczenie celu”);3) adekwatne, stosowne oraz ograniczone do tego, co niezbędne do celów, w których są przetwarzane („minimalizacja danych”); 4) prawidłowe i w razie potrzeby uaktualniane; należy podjać wszelkie rozsądne działania, aby dane osobowe, które są nieprawidłowe w świetle celów ich przetwarzania, zostały niezwłocznie usunięte lub sprostowane („prawidłowość”); 5) przechowywane w formie umożliwiającej identyfikację osoby, której dane dotyczą, przez okres nie dłuższy, niż jest to niezbędne do celów, w których dane te są przetwarzane; dane osobowe można przechowywać przez okres dłuższy, o ile będą one przetwarzane wyłącznie do celów archiwalnych

${ }^{23}$ Por. P. Fajgielski, Ogólne rozporządzenie o ochronie danych. Ustawa o ochronie danych osobowych. Komentarz, Warszawa 2018, komentarz do art. 9 pkt 23 rozporządzenia nr 2016/679 w sprawie ochrony osób fizycznych w związku z przetwarzaniem danych osobowych i w sprawie swobodnego przepływu takich danych oraz uchylenia dyrektywy 95/46/WE (ogólne rozporządzenie o ochronie danych). 
w interesie publicznym, do celów badań naukowych lub historycznych lub do celów statystycznych, z zastrzeżeniem, że wdrożone zostaną odpowiednie środki techniczne i organizacyjne wymagane na mocy rozporządzenia $\mathrm{w}$ celu ochrony praw i wolności osób, których dane dotyczą („ograniczenie przechowywania”); 6) przetwarzane w sposób zapewniający odpowiednie bezpieczeństwo danych osobowych, w tym ochronę przed niedozwolonym lub niezgodnym z prawem przetwarzaniem oraz przypadkową utrata, zniszczeniem lub uszkodzeniem, za pomocą odpowiednich środków technicznych lub organizacyjnych („integralność i poufność"). Dodatkowo w art. 5 ust. 2 RODO statuuje zasadę rozliczalności, która oznacza, że administrator jest odpowiedzialny za przestrzeganie przepisów ust. 1 i musi być w stanie wykazać ich przestrzeganie. W literaturze wskazano, że rozliczalność ochrony danych znalazła się w tym samym przepisie co pozostałe zasady ogólne (art. 5 RODO), ale została umieszczona w odrębnej jednostce redakcyjnej, gdyż zasada ta odnosi się do wszystkich pozostałych zasad ogólnych ${ }^{24}$.

W niniejszym opracowaniu przywołane zostaną przepisy służące ochronie danych dotyczących zdrowia, które podlegają zbieraniu i przetwarzaniu w ramach systemu opieki zdrowotnej jako subsystemu zabezpieczenia społecznego. O ile bowiem kwestie dotyczące zbierania i przetwarzania danych dotyczących zdrowia przez rozmaite podmioty, które z punktu widzenia organizacji systemu opieki zdrowotnej zbiorczo określić można mianem świadczeniodawców, były przedmiotem - także krytycznych - analiz ${ }^{25}$, to regulacja dotycząca NFZ jako organizatora systemu (oraz podmiotów władzy publicznej, którym w systemie przyznano określone kompetencje i zadania) nie doczekała się dotąd - na ile zdołano ustalić - omówienia.

\footnotetext{
${ }^{24}$ Por. A. Mednis, op. cit., s. 941.

${ }^{25}$ Por. ibidem; Ustawa o prawach pacjenta i Rzeczniku Praw Pacjenta. Komentarz, pod red. L. Boska, Warszawa 2020, komentarz do art. 13; D. Karkowska, Ustawa o prawach pacjenta i Rzeczniku Praw Pacjenta. Komentarz, Warszawa 2016, komentarz do art. 13; J. Barta, P. Fajgielski, R. Markiewicz, Ochrona danych osobowych. Komentarz, Warszawa 2011; M. Jackowski, Ochrona danych medycznych, Warszawa 2002; P. Fajgielski, Komentarz...; P. Litwiński, Powierzenie danych medycznych do przetwarzania. Umowy dotyczace danych osobowych medycznych, w: K. Andres i in., Ochrona danych osobowych medycznych, Warszawa 2018; M. Krasińska, Przetwarzanie danych osobowych w dokumentacji medycznej, w: K. Andres i in., Ochrona danych osobowych...; M. Jagielski, Pojęcie danych medycznych i zasady ich ochrony, w: K. Andres i in., Ochrona danych osobowych...; K. Świtała, Odpowiedzialność podmiotów wykonujących działalność lecznicza za przetwarzanie zasobów informacyjnych dotyczacych pacjentów w kontekście unijnej reformy regulacji ochrony danych osobowych, w: Odpowiedzialność w ochronie zdrowia, pod red. E. Kruk, A. Wołoszyn-Cichockiej, M. Zdyba, Warszawa 2018.
} 


\section{Przetwarzanie i ochrona danych w ustawie o świadczeniach opieki zdrowotnej finansowanych ze środków publicznych}

Ustawa z dnia 27 sierpnia 2004 r. o świadczeniach opieki zdrowotnej finansowanych ze środków publicznych ${ }^{26} \mathrm{w}$ odrębnym i obszernym dziale VIII reguluje kwestie przetwarzania i ochrony danych. Artykuł 188 u.ś.o.z. precyzuje zarówno dane osobowe, jakie mogą być przetwarzane, jak i cele, którym przetwarzanie to ma służyć. $W$ bardzo szerokim katalogu danych osobowych wskazano także dane dotyczące zdrowia. Są to dane mówiące o stopniu niepełnosprawności (art. 188 ust. 4 pkt 14 u.ś.o.z.) oraz o przyczynach (dotyczących stanu zdrowia) udzielenia świadczeń opieki zdrowotnej (art. 188 ust. 4 pkt 17 u.ś.o.z.) osobie, której dane są przetwarzane ${ }^{27}$. Co się natomiast tyczy dopuszczalnych celów przetwarzania, to zgodnie z ustawą są nimi: stwierdzanie istnienia ubezpieczenia zdrowotnego oraz prawa do świadczeń opieki zdrowotnej finansowanych przez Fundusz; wystawianie dokumentów uprawniających do korzystania ze świadczeń finansowanych przez Fundusz; stwierdzanie obowiązku płacenia składki i ustalenia kwoty składki; kontrola rodzaju, zakresu i przyczyny udzielanych świadczeń; potwierdzanie udzielenia świadczeń; przekazywanie świadczeniodawcom informacji istotnych dla procesu udzielania świadczeń zdrowotnych dotyczących świadczeniobiorców pozostających pod opieką tych świadczeniodawców, a dotyczących świadczeń udzielonych przez innych świadczeniodawców; rozliczanie ze świadczeniodawcami; rozliczanie z innymi instytucjami lub osobami w zakresie ich zobowiązań wobec Funduszu; kontrola przestrzegania zasad legalności, gospodarności, rzetelności i celowości finansowania udzielanych świadczeń zdrowotnych; monitorowanie stanu zdrowia i zapotrzebowania ubezpieczonych na świadczenia zdrowotne oraz leki i wyroby medyczne, w tym prowadzenia prac analitycznych i prognostycznych; monitorowanie realizacji indywidualnego prawa do świadczeń opieki zdrowotnej weteranów poszkodowanych; identyfikacja płatnika składek na ubezpieczenie zdrowotne; prowadzenie i utrzymywanie elektronicznego systemu monitorowania programów lekowych; prowadzenie prac analitycznych i prognostycznych związanych z realizacją świadczeń opieki zdrowotnej; prowadzenie i utrzymywanie

\footnotetext{
${ }^{26}$ Tekst jedn. Dz.U. 2019, poz. 1373 ze zm., dalej „u.ś.o.z.”.

27 Por. B. Łukasik, J. Nowak-Kubiak, Komentarz do art. 188-192, w: iidem, Ustawa o świadczeniach opieki zdrowotnej finansowanych ze środków publicznych. Komentarz, Warszawa 2006.
} 
elektronicznego systemu monitorowania programów zdrowotnych; przypominanie o wyznaczonym terminie udzielenia świadczenia opieki zdrowotnej; przekazywanie świadczeniobiorcom i świadczeniodawcom informacji z zakresu profilaktyki i zdrowego trybu życia, uzyskanych $\mathrm{w}$ ramach przetwarzania danych, a także rozliczanie kosztów refundacji leków, środków spożywczych specjalnego przeznaczenia żywieniowego i wyrobów medycznych (art. 188 ust. 1-2c u.ś.o.z.). NFZ może przetwarzać dane ubezpieczonych oraz innych świadczeniobiorców, a także osób uprawnionych do świadczeń na podstawie przepisów o koordynacji systemów zabezpieczenia społecznego.

Także minister zdrowia jest uprawniony do przetwarzania danych osobowych (w tym dotyczących zdrowia) wskazanych kategorii osób w celu: kontroli rodzaju, zakresu i przyczyny udzielonych tym osobom świadczeń, rozliczenia ze świadczeniodawcami za świadczenia wykonane na rzecz tych osób, rozliczenia z innymi instytucjami lub osobami w zakresie ich zobowiązań wobec NFZ, kontroli przestrzegania zasad legalności, gospodarności, rzetelności i celowości finansowania udzielanych świadczeń zdrowotnych oraz monitorowania stanu zdrowia i zapotrzebowania ubezpieczonych na świadczenia zdrowotne oraz leki i wyroby medyczne (w tym prowadzenia prac analitycznych i prognostycznych), a także w celu realizacji zadań związanych z prowadzeniem działań oraz współuczestniczeniem w działaniach związanych z promocją zdrowia i profilaktyką chorób, w tym w ramach programów polityki zdrowotnej oraz programów wieloletnich.

Należy uznać, że zarówno dane osobowe, jakie mogą być przetwarzane przez te instytucje, jak i cel ich przetwarzania stanowią katalog zamknięty. Oznacza to, że minister zdrowia oraz NFZ nie mogą przetwarzać innych danych osobowych niż wskazane w tym przepisie, jak też nie mogą przetwarzać tych danych w innych celach niż w nim wskazane. Niedopuszczalne jest zatem np. przetwarzanie danych osobowych ujętych w tym przepisie, jeśli zmierza to do realizacji innego celu niż wymieniony w art. 188 u.ś.o.z. ${ }^{28}$

Ponadto w ustawie określono stosowne uprawnienia jednostek samorządu terytorialnego oraz ministra obrony narodowej, ministra właściwego do spraw wewnętrznych, Szefa Agencji Bezpieczeństwa Wewnętrznego i Szefa Agencji Wywiadu, wynikające z ich zadań

${ }^{28}$ Por. A. Sidorko, Komentarz do art. 188 pkt 1, w: Ustawa o świadczeniach opieki zdrowotnej finansowanych ze środków publicznych. Komentarz, pod red. A. Pietraszewskiej-Machety, Warszawa 2018. 
odnoszących się do funkcjonowania systemu opieki zdrowotnej określonych grup świadczeniobiorców.

Odrębne przepisy uprawniają NFZ do zbierania i przetwarzania danych osobowych (ale niedotyczących zdrowia): osób wystawiających recepty na refundowane leki, środki spożywcze specjalnego przeznaczenia żywieniowego i wyroby medyczne, osób wystawiających zlecenie na zaopatrzenie $w$ wyroby medyczne, osób udzielających świadczeń na podstawie umów o udzielanie świadczeń opieki zdrowotnej oraz ubiegających się o zawarcie takich umów (art. 188a u.ś.o.z.), osób wykonujących zawody medyczne (art. 188b u.ś.o.z.), osób ubiegających się o nadanie dostępu lub korzystających z aplikacji udostępnianych przez Fundusz świadczeniodawcom oraz niebędącym świadczeniodawcami osobom uprawnionym i osobom przez nie upoważnionym, w celu korzystania z usług informatycznych i komunikacji z Funduszem (art. 188ba u.ś.o.z.).

\section{Przetwarzanie i ochrona danych w ustawie o systemie informacji w ochronie zdrowia}

Ustawa z dnia 28 kwietnia 2011 r. o systemie informacji w ochronie zdrowia $^{29}$ określa organizację i zasady działania systemu informacji w ochronie zdrowia, w którym przetwarzane są dane niezbędne do prowadzenia polityki zdrowotnej państwa, podnoszenia jakości i dostępności świadczeń opieki zdrowotnej oraz finansowania zadań z zakresu ochrony zdrowia, w tym także dane osobowe.

W zamkniętym katalogu art. 4 u.s.i.o.z. określono dane osobowe usługobiorców, jakie mogą być przetwarzane w systemie informacyjnym. Całość informacji zgromadzonych w rejestrze podzielono na trzy kategorie: dane osobowe usługobiorcy, jednostkowe dane medyczne oraz daty dokonania wpisów. Warto zauważyć, że ustawa nie posługuje się pojęciem "dane dotyczące zdrowia". Zezwala natomiast na zbieranie i przetwarzanie tzw. jednostkowych danych medycznych (art. 4 ust. 3 pkt 2 u.s.i.o.z.), co definiuje się jako dane osoby fizycznej o udzielonych, udzielanych i planowanych świadczeniach opieki zdrowotnej oraz dotyczące jej stanu zdrowia, $\mathrm{w}$ tym profilaktyki zdrowotnej i realizacji programów zdrowotnych (art. 2 pkt 7 u.s.i.o.z.). W świetle definicji danych dotyczących zdrowia oraz pkt 35 preambuły RODO należy

${ }^{29}$ Tekst jedn. Dz.U. 2020, poz. 702, dalej „u.s.i.o.z.”. 
uznać, że jednostkowe dane medyczne są niewątpliwie zespołem danych osobowych ${ }^{30}$, zawierającym także dane dotyczące zdrowia, ich przetwarzanie podlega zatem zasadom respektującym ochronę wrażliwych danych osobowych. Odnosząc się do podziału danych na trzy kategorie, w piśmiennictwie trafnie wskazano, że podział ten jest o tyle niezrozumiały, że jednostkowe dane medyczne, o ile można zidentyfikować osobę, której dotycza, są również danymi osobowymi. Podobnie jest $\mathrm{w}$ przypadku daty dokonania wpisu - może być w pewnych przypadkach istotną daną osobowa, świadczącą m.in. o okresie, w jakim pacjent cierpiał na określoną chorobę ${ }^{31}$.

System informacji obejmuje bazy danych ${ }^{32}$ tworzone przez wskazane w ustawie podmioty obowiązane do ich prowadzenia, zawierające dane o: 1) udzielonych, udzielanych i planowanych świadczeniach opieki zdrowotnej, 2) usługodawcach i pracownikach medycznych oraz 3) usługobiorcach (art. 3 ust. 1 u.s.i.o.z.). Warto zauważyć, że bazy danych o udzielonych, udzielanych i planowanych świadczeniach opieki zdrowotnej prowadzą nie tylko świadczeniodawcy, tj. podmioty wykonujące działalność leczniczą w rozumieniu przepisów ustawy o działalności leczniczej (m.in. publiczne zakłady opieki zdrowotnej, instytuty badawcze i podmioty gospodarcze prowadzące działalność leczniczą), osoby fizyczne, które posiadają fachowe uprawnienia do udzielania świadczeń zdrowotnych i udzielają ich w ramach wykonywanej działalności gospodarczej oraz podmiot realizujący czynności $\mathrm{z}$ zakresu zaopatrzenia $\mathrm{w}$ wyroby medyczne, ale także rozmaite podmioty finansujące lub współfinansujące udzielenie świadczeń opieki zdrowotnej (NFZ, jednostki samorządu terytorialnego i inni) w odniesieniu do świadczeniobiorców, w stosunku do których są obowiązani do sfinansowania lub współfinansowania świadczeń opieki zdrowotnej. Ponadto dane te przetwarzają podmioty władzy publicznej - minister właściwy do spraw zdrowia oraz wojewoda - w zakresie zadań związanych z zapewnieniem równego dostępu do świadczeń opieki zdrowotnej.

Do systemu informacji zalicza się bazy danych funkcjonujące w ramach: 1) Systemu Informacji Medycznej (SIM); 2) dziedzinowych

${ }^{30}$ Por. A. Mednis, op. cit., s. 947-948.

${ }^{31}$ Por. ibidem.

${ }^{32}$ Odnośnie do wielości i nieprzejrzystości baz danych wymagających ujednolicenia por. K. Świtała, Pacjent jako beneficjent ograniczeń jawności elektronicznej dokumentacji medycznej, Warszawa 2018, s. 9 i n. 
systemów teleinformatycznych, tj. Systemu Rejestru Usług Medycznych Narodowego Funduszu Zdrowia, Systemu Statystyki w Ochronie Zdrowia, Systemu Ewidencji Zasobów Ochrony Zdrowia, Systemu Monitorowania Zagrożeń, Systemu Monitorowania Dostępności do Świadczeń Opieki Zdrowotnej, Systemu Monitorowania Kosztów Leczenia, Zintegrowanego System Monitorowania Obrotu Produktami Leczniczymi, Systemu Monitorowania Kształcenia Pracowników Medycznych, Systemu Obsługi List Refundacyjnych, Instrumentu Oceny Wniosków Inwestycyjnych w Sektorze Zdrowia oraz Rejestru Asystentów Medycznych; 3) rejestrów medycznych, tj. tworzonych zgodnie z prawem rejestrów, ewidencji, list, spisów albo innych uporządkowanych zbiorów danych osobowych, jednostkowych danych medycznych lub danych niebędących danymi osobowymi, służących do realizacji zadań publicznych, prowadzonych przez podmiot funkcjonujący w systemie ochrony zdrowia (art. 5 ust. 1 u.s.i.o.z.).

Z punktu widzenia danych dotyczących zdrowia zasadnicze znaczenie ma System Informacji Medycznej, będący systemem teleinformatycznym służącym przetwarzaniu danych dotyczących udzielonych, udzielanych i planowanych świadczeń opieki zdrowotnej udostępnianych przez systemy teleinformatyczne usługodawców (art. 10 u.s.i.o.z.). Nawiązując do wyrażonej w RODO zasady ograniczenia celu istotne jest, że ustawodawca sprecyzował cele przetwarzania danych, $w$ tym danych osobowych, w ramach SIM (art. 12 ust. 1 u.s.i.o.z.). Wyszczególniono tu cele istotne z punktu widzenia zarówno pacjentów (poprawa dostępności świadczeniobiorców do świadczeń opieki zdrowotnej finansowanych lub współfinansowanych ze środków publicznych, umożliwienie świadczeniobiorcom uzyskiwania informacji o udzielanych, udzielonych i planowanych świadczeniach opieki zdrowotnej, prawie do świadczeń opieki zdrowotnej, liczbie oczekujących na udzielenie świadczenia opieki zdrowotnej, średnim czasie oczekiwania na udzielenie świadczenia opieki zdrowotnej oraz pierwszym wolnym terminie udzielenia świadczenia opieki zdrowotnej, umożliwienie składania przez pacjentów wniosków, umożliwienie wymiany danych o pacjentach w związku z leczeniem itd.), jak i z perspektywy interesu publicznego (monitorowanie równego dostępu do świadczeń, dokonywanie przez uprawnione podmioty oceny zapotrzebowania na świadczenia opieki zdrowotnej). W ustawie o systemie informacji w ochronie zdrowia prawodawca wyznaczył również ministra właściwego do spraw zdrowia jako administratora danych przetwarzanych w SIM (art. 10 ust. 8 u.s.i.o.z.) ${ }^{33}$.

${ }^{33}$ Por. A. Mednis, op. cit., s. 949-950. 
Spośród dziedzinowych systemów teleinformatycznych przywołać należy zwłaszcza Rejestr Usług Medycznych (RUM-NFZ), którego celem jest przetwarzanie danych o udzielonych i planowanych świadczeniach opieki zdrowotnej finansowanych ze środków publicznych oraz rozliczanie tych świadczeń. Administratorem danych przetwarzanych w systemie RUM-NFZ jest Narodowy Fundusz Zdrowia (art. 22 u.s.i.o.z.). Istotne znaczenie z punktu widzenia ochrony danych dotyczących zdrowia ma także RAM. Jest to system teleinformatyczny, w którym przetwarzane są dane o pracownikach medycznych i osobach wykonujących zawód medyczny, o których mowa w art. 2 ust. 1 pkt 2 Ustawy z dnia 15 kwietnia 2011 r. o działalności leczniczej ${ }^{34}$, lub czynności pomocnicze przy udzielaniu świadczeń zdrowotnych, o których mowa w art. 24 ust. 2 pkt 2 Ustawy z dnia 6 listopada 2008 r. o prawach pacjenta i Rzeczniku Praw Pacjenta ${ }^{35}$. System RAM pozwala zatem zidentyfikować podmioty należące do kręgu osób uprawnionych do przetwarzania danych zawartych w dokumentacji medycznej (por. art. 9 ust. 2 lit. h RODO).

Podkreślenia wymaga, że dane zgromadzone w systemie informacyjnym są dostępne dla świadczeniobiorców (por. art. 15 RODO $^{36}$ ). Służy temu Elektroniczna Platforma Gromadzenia, Analizy i Udostępnienia Zasobów Cyfrowych o Zdarzeniach Medycznych, która zapewnia m.in. dostęp świadczeniobiorców do informacji o udzielonych i planowanych świadczeniach opieki zdrowotnej zgromadzonych w SIM oraz raportów z udostępnienia danych ich dotyczących (art. 7 ust. 1 u.s.i.o.z.). Pacjent może otrzymać dostęp do powyższych informacji i raportów oraz informacji o kwocie środków publicznych wydatkowanych na sfinansowanie udzielonych mu świadczeń opieki zdrowotnej za pośrednictwem Internetowego Konta Pacjenta (art. 7a i 7b u.s.i.o.z.) ${ }^{37}$.

W kontekście ochrony danych osobowych przywołać też należy art. 37 u.s.i.o.z., zgodnie z którym podmioty prowadzące bazy danych w zakresie ochrony zdrowia są obowiązane do stworzenia warunków organizacyjnych i technicznych zapewniających ochronę przetwarzanych

${ }^{34}$ Tekst jedn. Dz.U. 2020, poz. 295.

35 Tekst jedn. Dz.U. 2020, poz. 849.

${ }^{36}$ Przepis ten obejmuje w istocie wiązkę czterech uprawnień osoby, której dane dotycza, tj.: uprawnienie do uzyskania od administratora potwierdzenia, czy przetwarzane są dane osobowe jej dotyczące; uprawnienie do uzyskania dostępu do tych danych; uprawnienie do uzyskania określonych informacji; prawo do uzyskania kopii przetwarzanych przez administratora danych jej dotyczących (A. Mednis, op. cit. s. 965).

${ }^{37}$ Por. ibidem, s. 966. 
danych, w szczególności zabezpieczenia danych przed nieuprawnionym dostępem, nielegalnym ujawnieniem lub pozyskaniem, a także ich modyfikacja, uszkodzeniem, zniszczeniem lub utratą.

\section{Szczególna regulacja dotycząca pandemii COVID-19}

Zasadniczo prawo zdrowia publicznego, którego przedmiotem jest m.in. zwalczanie chorób epidemicznych ${ }^{38}$, jest odrębnym od prawa opieki zdrowotnej elementem prawa ochrony zdrowia ${ }^{39}$. Niemniej szczególna sytuacja związana z pandemią COVID-19 i wprowadzeniem licznych przepisów służących ograniczeniu jej zasięgu, a odnoszących się także do przetwarzania danych dotyczących zdrowia, uzasadnia ich omówienie $w$ ramach niniejszego opracowania.

Jeszcze przed wybuchem pandemii art. 32a ust. 1 Ustawy z dnia 5 grudnia 2008 r. o zapobieganiu oraz zwalczaniu zakażeń i chorób zakaźnych u ludzi ${ }^{40}$ przewidywał, że Państwowy Inspektor Sanitarny lub Główny Inspektor Sanitarny w związku z prowadzonym dochodzeniem epidemiologicznym może żądać udzielenia informacji o osobach zakażonych lub podejrzanych o zakażenie, chorych lub podejrzanych o chorobę zakaźna, osobach zmarłych z powodu choroby zakaźnej lub osobach, wobec których istnieje takie podejrzenie, oraz o osobach, które mogły mieć styczność z takimi osobami. Żądanie mogło przy tym obejmować m.in. dane, które należy zakwalifikować jako dane dotyczące zdrowia, tj. rozpoznanie kliniczne zakażenia lub choroby zakaźnej oraz charakterystykę podstawowych objawów klinicznych i biologicznego czynnika chorobotwórczego, a także okoliczności narażenia na zakażenie, ze szczególnym uwzględnieniem czynników ryzyka (art. 32 ust. 2 pkt 8 i 9 przywołanego aktu).

W ramach szczególnego ustawodawstwa związanego z zapobieganiem, przeciwdziałaniem i zwalczaniem COVID-1941 postanowiono, że prawo przetwarzania i przekazywania właściwym organom

${ }^{38}$ Por. M. Dercz, H. Izdebski, Organizacja ochrony zdrowia w Rzeczypospolitej Polskiej w świetle obowiązującego ustawodawstwa, Warszawa-Poznań 2001, s. 11.

${ }^{39}$ Por. D.E. Lach, Zasada równego dostępu do świadczeń opieki zdrowotnej, Warszawa 2011, s. 130 i n.

${ }^{40}$ Tekst jedn. Dz.U. 2019, poz. 1239 ze zm.

${ }^{41}$ Ustawa z dnia 2 III 2020 r. o szczególnych rozwiązaniach związanych z zapobieganiem, przeciwdziałaniem i zwalczaniem COVID-19, innych chorób zakaźnych oraz wywołanych nimi sytuacji kryzysowych (Dz.U. poz. 374), zmieniona Ustawą z dnia 16 IV 
Państwowej Inspekcji Sanitarnej danych osobowych (w tym również dotyczących zdrowia - lege non distinguente nec nostrum distinguere) określonych w decyzjach, zaleceniach lub wytycznych, o których mowa w art. 8a ust. 5 Ustawy z dnia 14 marca 1985 r. o Państwowej Inspekcji Sanitarnej ${ }^{42}$, przysługuje także organom administracji publicznej wykonującym takie decyzje, zalecenia lub wytyczne albo współdziałającym $\mathrm{w}$ realizacji zadań $\mathrm{z}$ zakresu ochrony zdrowia publicznego przed zakażeniami i chorobami zakaźnymi (por. art. 15zzzzzh (sic!) ustawy z dnia 2 marca 2020 r.). W literaturze zauważono w tym kontekście, że możliwość wydawania takich decyzji została ograniczona do sytuacji stanu zagrożenia epidemicznego, stanu epidemii albo do niebezpieczeństwa szerzenia się zakażenia lub choroby zakaźnej, które może stanowić zagrożenie dla zdrowia publicznego, w szczególności wystąpienia choroby szczególnie niebezpiecznej lub wysoce zakaźnej. Niemniej takie ogólnikowo sformułowane kompetencje były przyczyną dość kontrowersyjnej praktyki nakładania na przedsiębiorców (często zresztą na ich wniosek) obowiązku mierzenia temperatury pracownikom przy wejściu do zakładu pracy, zbierania danych o stanie zdrowia, przebywaniu na kwarantannie ${ }^{43}$. Co więcej, praktykę taką poparł Prezes UODO, stwierdzając w komunikacie z dnia 27 marca 2020 r., że „wszelkie decyzje, wytyczne oraz zalecenia GIS wydawane różnym podmiotom na podstawie tej specustawy będą stanowić podstawę prawną do przetwarzania przez nie danych osobowych" ${ }^{\prime 4}$. W efekcie doszło do usankcjonowania praktycznie nieograniczonego zbierania danych o stanie zdrowia bez zapewnienia odpowiednich zabezpieczeń, okresów retencji itp. ${ }^{45} \mathrm{Na}$ marginesie tylko dostrzec trzeba, że zgodnie z art. 11d ust. 2 ustawy z dnia 2 marca 2020 r. „wszystkie informacje, $\mathrm{w}$ tym dane osobowe uzyskane $\mathrm{w}$ toku realizacji przez Policję czynności służących zapobieganiu szerzeniu się zakażeń i chorób zakaźnych, o których mowa w art. 34 ust. 1-3 Ustawy z dnia 5 grudnia 2008 r. o zapobieganiu oraz zwalczaniu zakażeń i chorób zakaźnych u ludzi, usuwa się lub niszczy w terminie jednego miesiąca po upływie obowiązywania niniejszej ustawy".

\footnotetext{
2020 r. o szczególnych instrumentach wsparcia w związku z rozprzestrzenianiem się wirusa SARS-CoV-2 (Dz.U. poz. 695).

42 Tekst jedn. Dz.U. 2019, poz. 59.

${ }^{43}$ Por. A. Mednis, op. cit., s. 959-960.

${ }^{44}$ DOL.023.347.2020, por. https://uodo.gov.pl/pl/138/1471 (dostęp: 17 VI 2020).

${ }^{45}$ Por. A. Mednis, op. cit., s. 959-960.
} 


\section{Podsumowanie}

Reasumując, należy zauważyć, że niektóre z omawianych przepisów zostały wprowadzone jeszcze jako wykonanie dyrektywy 95/46/WE. Inne zostały wprowadzone $\mathrm{w}$ związku z pracami przygotowawczymi nad RODO i podczas nich. Do tej pory w literaturze nie zgłaszano uwag odnośnie do ich zgodności z zasadami ustalonymi prawem wspólnotowym. Zasadniczo bowiem regulacje dotyczące zarówno zbierania, jak i przetwarzania danych dotyczących zdrowia jako danych wrażliwych na potrzeby funkcjonowania systemu opieki zdrowotnej jako subsystemu zabezpieczenia społecznego organizowanego przez NFZ respektują zasady określone $w$ art. 5 RODO. Ustawy wytyczają ramy prawne odnośnie do przetwarzania danych osobowych osób uprawnionych do świadczeń opieki zdrowotnej finansowanej ze środków publicznych, określając konkretne, wyraźne i prawnie uzasadnione cele, dla których są one zbierane i przetwarzane. W szczególności ustalono, że przepisy Ustawy z dnia 27 sierpnia 2004 r. o świadczeniach opieki zdrowotnej finansowanych ze środków publicznych w zamkniętym katalogu zarówno precyzują dane osobowe, w tym oczywiście dotyczące zdrowia, jakie mogą być przetwarzane przez instytucje systemu opieki zdrowotnej (przede wszystkim NFZ i ministra zdrowia, ale także inne podmioty finansujące lub współfinansujące udzielanie świadczeń opieki zdrowotnej, np. jednostki samorządu terytorialnego), jak i definiują cel ich przetwarzania. Również w Ustawie z dnia 28 kwietnia 2011 r. o systemie informacji w ochronie zdrowia wskazano, jakie podmioty są zobowiązane do prowadzenia rozmaitych baz danych składających się na system informacji, oraz sprecyzowano cele przetwarzania określonych danych. Warto dostrzec, że w ustawie wyszczególniono cele istotne zarówno z punktu widzenia pacjentów, jak i z perspektywy interesu publicznego. Trzeba przy tym zauważyć, że przywołana ustawa nie posługuje się pojęciem "danych dotyczących zdrowia". Niemniej jednak, biorąc pod uwage definicję tych danych (art. 4 pkt 15 RODO) oraz pkt 35 preambuły RODO, należy uznać, że jednostkowe dane medyczne są niewątpliwie zespołem danych osobowych zawierającym także dane dotyczące zdrowia. Można też uznać, że zbierane i przetwarzane dane są adekwatne, stosowne i ograniczone do tego, co niezbędne do celów, w jakich są przetwarzane. W interesie samego organizatora jest ponadto zapewnienie, aby dane były prawidłowe i w razie potrzeby uaktualniane oraz przechowywane $\mathrm{w}$ formie 
umożliwiającej identyfikację osoby, której dotycza, przez okres nie dłuższy, niż jest to niezbędne do celów, w których dane te są przetwarzane. Wydaje się także, że prowadzenie określonych baz danych i systemów teleinformatycznych przez jednostki władzy publicznej zapewnia przetwarzanie zebranych danych w sposób zapewniający odpowiednie bezpieczeństwo danych osobowych, w tym ochronę przed niedozwolonym lub niezgodnym z prawem przetwarzaniem oraz przypadkową utrata, zniszczeniem lub uszkodzeniem, za pomoca odpowiednich środków technicznych lub organizacyjnych.

Mimo tych optymistycznych konkluzji na zakończenie należy jednak zauważyć, że na tle ustawodawstwa związanego z zapobieganiem, przeciwdziałaniem i zwalczaniem COVID-19 wykształciła się w wielu miejscach, za aprobatą Prezesa UODO, praktyka w zasadzie nieograniczonego zbierania danych o stanie zdrowia, bez zapewnienia respektowania zasad ochrony danych określonych w RODO. Jakkolwiek stan epidemii uzasadnia wprowadzanie ad hoc incydentalnych regulacji szczególnych, to jednak wydaje się, że nie powinny one całkowicie abstrahować od ochrony danych zarówno szczególnych, jak i wrażliwych, takich jak dane dotyczące zdrowia.

\section{PROCESSING AND PROTECTION OF DATA CONCERNING HEALTH BY THE HEALTH CARE ORGANIZER}

\section{Sum mary}

The protection of individuals regarding to the processing of personal data is one of the fundamental rights. The General Data Protection Regulation (GDPR) lays down rules relating to the protection of natural persons with regard to the processing of personal data and rules relating to the free movement of personal data. Data concerning health is one of the areas the GDPR defines as special personal data, the so-called sensitive data. With regard to these data, the GDPR allows their processing only on an exceptional basis, in certain situations. According to Art. 6 sec. 1 let. e GDPR and art. 9 sec. 2 let. b GDPR, data processing is allowed, inter alia, when such processing is necessary for the purposes of meeting the obligations and exercising specific rights of the controller or of the data subject in the field of employment and social security and social protection law. In turn, Art. 9 sec. 2 let. h GDPR permits the processing of health data that is necessary for the purposes of providing health or social care or treatment, or for managing health or social care systems and services on the basis of European Union or Member State law. The article discusses the national legal regulations regarding the collection and processing of personal data concerning health in the light of the organization of the health care system and the 
tasks of the National Health Fund (NFZ) as a placeholder, whose task is only to manage financial resources and conclude health care contracts on its own behalf with independent healthcare providers and their accounting. Against the background of the GDPR, the author discusses the provisions of the acts on health care services financed from public funds and on the information system in health care. Finally, specific regulation regarding the COVID-19 pandemic are presented.

Keywords: data concerning health - health-care system - National Health Fund (NFZ) - General Data Protection Regulation

\section{LITERATURA}

Barta J., Fajgielski P., Markiewicz R., Ochrona danych osobowych. Komentarz, Warszawa 2011.

Bauer H., Privatisierung oder Publizisierung?, w: Publizisierung öffentlicher Aufgaben, Hrsg. von H. Bauer, M. Szewczyk, B. Popowska, M. Meier, A. Fuks, Potsdam 2018.

Bauer H., Von der Privatisierung zur Rekommunalisierung, w: Rekommunalisierung öffentlicher Daseinsvorsorge, Hrsg. von H. Bauer, Ch. Büchner, L. Hajasch, Potsdam 2012.

Biernat S., Prywatyzacja zadań publicznych. Problematyka prawna, Warszawa-Kraków 1994.

Ustawa o prawach pacjenta i Rzeczniku Praw Pacjenta. Komentarz, pod red. L. Boska, Warszawa 2020.

Buchner B., Schwichtenberg S., Gesundheitsdatenschutz unter der Datenschutz-Grundverordnung, "Gesundheit und Praxis" 2016, Nr. 6.

Dercz M., Izdebski H., Organizacja ochrony zdrowia w Rzeczypospolitej Polskiej w świetle obowiazujacego ustawodawstwa, Warszawa-Poznań 2001.

Dmochowska A., Przetwarzanie danych szczególnych kategorii, w: A. Dmochowska, M. Zadrożny, Unijna reforma ochrony danych osobowych. Analiza zmian, Warszawa 2016.

Fajgielski P., Komentarz do rozporzadzenia nr 2016/679 w sprawie ochrony osób fizycznych w zwiazku z przetwarzaniem danych osobowych $i$ w sprawie swobodnego przeptywu takich danych oraz uchylenia dyrektywy 95/46/WE (ogólne rozporządzenie o ochronie danych), w: P. Fajgielski, Ogólne rozporzadzenie o ochronie danych. Ustawa o ochronie danych osobowych. Komentarz, Warszawa 2018.

Franzius C., Der "Gewährleistungsstaat" - ein neues Leitbild für den sich wandelnden Staat?, "Der Staat" 2003, Bd. 42.

Franzius C., Die Europäische Dimension des Gewährleistungsstaates, „Der Staat” 2006, Bd. 45.

Franzius C., Gewährleistung im Recht. Grundlagen eines europäischen Regelungsmodells öffentlicher Dienstleistungen, Tübingen 2009.

Jackowski M., Ochrona danych medycznych, Warszawa 2002. 
Jagielski M., Pojęcie danych medycznych i zasady ich ochrony, w: K. Andres i in., Ochrona danych osobowych medycznych, Warszawa 2018.

Jończyk J., Glosa do wyroku SN z dnia 10 grudnia 2004 r., III CK 134/04, OSP 2005, z. 6. Jończyk J., Trudna modernizacja opieki zdrowotnej w Niemczech i w Zjednoczonym Królestwie (UK), „Praca i Zabezpieczenie Społeczne” 2006, nr 6.

Karkowska D., Ustawa o prawach pacjenta i Rzeczniku Praw Pacjenta. Komentarz, Warszawa 2016.

Krasińska M., Przetwarzanie danych osobowych w dokumentacji medycznej, w: K. Andres i in., Ochrona danych osobowych medycznych, Warszawa 2018.

Krasińska, P. Litwiński, A. Sieradzka, K. Wojsyk, Ochrona danych osobowych medycznych, Warszawa 2018.

Kuba M. Komentarz do art. 9, pkt 9, w: RODO. Ogólne rozporządzenie o ochronie danych. Komentarz, pod red. E. Bielak-Jomaa, D. Lubasza, Warszawa 2018.

Lach D.E., Pojęcie i systematyka prawa ubezpieczeń społecznych, w: System prawa ubezpieczeń społecznych, t. 1, pod red. A. Wypych-Żywickiej, Warszawa 2020.

Lach D.E., Powiernicza technika realizacji zabezpieczenia społecznego (na przykładzie ubezpieczenia zdrowotnego), "Państwo i Prawo” 2009, z. 3.

Lach D.E., Powierzanie realizacji zadań publicznych z zakresu zabezpieczenia społecznego podmiotom niepublicznym, "Państwo i Prawo” 2015, z. 2.

Lach D.E., Tendencje rozwojowe "ubezpieczenia zdrowotnego" - kilka uwag na marginesie zapowiadanej publicyzacji systemu opieki zdrowotnej, w: Tendencje rozwojowe indywidualnego i zbiorowego prawa pracy. Ksiegga jubileuszowa Profesora Grzegorza Goździewicza, Toruń 2017.

Lach D.E., Zasada równego dostępu do świadczeń opieki zdrowotnej, Warszawa 2011.

Litwiński P., Powierzenie danych medycznych do przetwarzania. Umowy dotyczace danych osobowych medycznych, w: K. Andres i in., Ochrona danych osobowych medycznych, Warszawa 2018.

Łukasik B., Nowak-Kubiak J., Komentarz do art. 188-192, w: iidem, Ustawa o świadczeniach opieki zdrowotnej finansowanych ze środków publicznych. Komentarz, Warszawa 2006.

Mednis A., Ochrona danych osobowych w systemie ochrony zdrowia. Zasady prowadzenia, udostepniania i archiwizowania dokumentacji medycznej, w: Organizacja systemu ochrony zdrowia. System Prawa Medycznego, t. 3, pod red. D. Bach-Goleckiej, R. Stankiewicza, Warszawa 2020.

Schäfer R., Rekommunalisierung - Fallstricke in der Praxis w: Rekommunalisierung öffentlicher Daseinsvorsorge, Hrsg. von H. Bauer, Ch. Büchner, L. Hajasch, Potsdam 2012.

Sidorko A., Komentarz do art. 188 pkt 1, w: Ustawa o świadczeniach opieki zdrowotnej finansowanych ze środków publicznych. Komentarz, pod red. A. Pietraszewskiej-Machety, Warszawa 2018.

Szurgacz H., Zagadnienie przekazywania przez państwo zadań w zakresie zabezpieczenia społecznego podmiotom niepublicznym, w: Konstytucyjne problemy prawa pracy i zabezpieczenia społecznego. Referaty na XV Zjazd Katedr i Zakładów Prawa Pracy i Ubezpieczeń Społecznych, Wrocław 1-2 czerwca 2005 r., pod red. H. Szurgacza, Wrocław 2005. 
Świtała K., Odpowiedzialność podmiotów wykonujących działalność leczniczą za przetwarzanie zasobów informacyjnych dotyczacych pacjentów w kontekście unijnej reformy regulacji ochrony danych osobowych, w: Odpowiedzialność w ochronie zdrowia, pod red. E. Kruk, A. Wołoszyn-Cichockiej, M. Zdyba, Warszawa 2018.

Świtała K., Pacjent jako beneficjent ograniczeń jawności elektronicznej dokumentacji medycznej, Warszawa 2018.

Treutner E., Kooperativer Rechtsstaat. Das Beispiel Sozialverwaltung, Baden-Baden 1998. 